\title{
Pembuatan Website Wisata Desa Gajahrejo dalam Meningkatkan Daya Saing sebagai Desa Wisata Sekaligus Memasarkan Produk Unggulan Desa
}

\author{
Dediek Tri Kurniawan ${ }^{1}$, Arum Prasasti ${ }^{2}$, Raisa Fitri ${ }^{3}$, Inanda Shinta Anugrahani ${ }^{4}$, Yesiana Ihda Kusnayain ${ }^{5}$ \\ 1,2,3,5 Jurusan Manajemen, Universitas Negeri Malang, Malang, Indonesia \\ ${ }^{4}$ Jurusan Akuntansi, Universitas Negeri Malang, Malang, Indonesia \\ ${ }^{1}$ dediek.kurniawan.fe@um.ac.id
}

\begin{abstract}
Indonesia is a country with good economic growth, one of the main contributors of gross domestic product (GDP) is the tourism sector. The country's foreign exchange receipts from the sector continued to grow to US\$16.11 Billion in 2018. The existence of tourist villages is now a concern of the government in increasing economic equality and reducing the Gini ratio from Indonesia. The potential of tourist villages is huge, about 1,734 potential tourist villages that have the potential to be developed salag the only one is Gajahrejo village located south of malang regency. Gajahrejo village has tremendous economic potential with its wealth and superior products. So, the creation of a website is one of the solutions to the economic improvement of Gajahrejo village. By using waterfall method in the development process that begins with analysis until maintenance is able to provide outstanding website results, by going through 3 stages namely preparation, implementation, and evaluation. With the process and methods used produced a website that serves as a data center and the sale of products from Gajahrejo village as an effort to strengthen the branding of the village.
\end{abstract}

Keywords: Gajahrejo.id, Waterfall, Branding

\section{Abstrak}

Indonesia merupakan negara dengan pertumbuhan ekonomi yang baik, salah satu kontributor utama dari gross domestic product (GDP) adalah sector wisata. Penerimaan devisa negara dari sector ini terus tumbuh hingga mencapai US\$16,11 Miliar pada 2018. Keberadaan desa wisata saat ini menjadi perhatian pemerintah dalam meningkatkan pemerataan ekonomi dan memperkecil rasio gini dari Indonesia. Potensi desa wisata sangat besar, sekitar 1.734 potensi desa wisata yang berpotensi untuk dikembangkan salah satunya adalah desa Gajahrejo yang terletak selatan kabupaten malang. Desa gajahrejo memiliki potensi ekonomi yang luar biasa dengan kekayaan dan produk unggulan yang ada. Sehingga pembuatan website adalah salah satu solusi peningkatan ekonomi desa Gajahrejo ini. Dengan menggunakan metode waterfall dalam proses pengembangan yang diawali dengan analisis hingga maintenance ini mampu memberikan hasil website yang luar biasa, dengan melalui 3 tahap yaitu persiapan, pelaksanaan, dan evaluasi. Dengan proses dan metode yang digunakan dihasilkan sebuah website yang berfungsi sebagai pusat data dan penjualan produk-produk dari desa Gajahrejo sebagai upaya penguatan branding dari desa tersebut.

Kata Kunci: Gajahrejo.id, waterfall, branding 


\section{PENDAHULUAN}

Potensi wisata Indonesia masih terbukti mampu meningkatkan devisa negara serta mampu dalam berkontribusi pada gross domestic product (GDP) maupun pendapatan daerah. Penerimaan devisa dari sektor pariwisata di Indonesia terus tumbuh dari 2015 yaitu sekitar US\$ 12,23 miliar menjadi US\$ 16,11 miliar pada 2018. Dalam mengenjot peningkatan kontribusi sektor pariwisata, investasi pemerintah terhadap sektor pariwisata telah mencapai 170 triliun. Hal ini ditujukan dalam pengembangan 10 "Bali" baru dengan target 25 juta kunjungan wisatawan mancanegara dan 300 juta perjalanan wisatawan lokal pada tahun 2024. Selama ini kinerja sektor wisata juga cukup cemerlang. Pada tahun 2018, sektor pariwista mampu menyerap sekutar 12,7 juta orang.

Dalam memacu peran pariwisata dalam mendongkrak pertumbuhan ekonomi yang berkelanjutan, pemerintah juga gencar dalam membangun potensi desa wisata. Keberadaan desa wisata ini menjadi perhatian pemerintah dalam meningkatkan pemerataan ekonomi di diperdesaaan. Potensinya pun juga sangat besar mengingat tidak sedikit jumlah desa yang memiliki potensi wsiata. Menurut data Badan Pusat Statistik (BPS) pada tahun 2018, tercatat terdapat sekitar 1.734 potensi desa wisata yang belum di kembangkan sehingga berpotensi menjadi objek wisata unggulan. Hal ini juga mendorong pemerintah gencar dalam pembangunan infrastruktur di desa. Dalam mempercepat pembangunan ekonomi dan infrasturktur desa, pemerintah telah mealokasikan Rp 188 triliun selama 2015-2018. Pada tahun 2018 saja, pemerintah telah menggelontorkan dana sekitar 60 triliun untuk dana desa. Dana tersebut diharapkan mampu membantu dalam percepatan pembangunan infrastruktur yang mendukung roda perekonomian.

Konsep desa wisata (rural tourism) telah menjadi faktor baru yang relevan dalam pembangunan pedesaan, menarik arus wisatawan ke daerah pedesaan dan memperkuat keuntungan daerah non-perkotaan (desa) melalui pendapatan tambahan dan kualitas hidup penduduk yang lebih baik, meningkatkan infrastruktur dan tingkat pekerjaan (Campón-Cerro et al., 2017). Di wilayah yang aktivitas ekonominya sedang menurun, pariwisata telah memposisikan sebagai harapan baru, terutama di tempattempat di mana pertanian tidak sekompetitif dulu (Guaita Martínez et al., 2019). Hal ini juga sering diperkuat keberadaan destinasi ekowisata yang terletak di daerah terpencil yang alami, sehingga sarana, termasuk infrastruktur, harus dibangun untuk melayani wisatawan (Hsu, 2019) (Tseng et al., 2019).

Pengembangan desa wisata juga tidak mudah mengingat setiap desa memiliki permasalahan tersendiri. Pengembangan desa wisata sering kali berhadapkan dengan lokasi, akses transportasi, fasilitas pendukung, minimnya
SDM, minimnya pengalaman pengelolaan, dan sebagainya. Hal ini tentu menyebabkan perlakuan pada masing-masing desa akan berbeda bergantung pada kondisi yang ada.

Desa Gajahrejo merupakan salah satu desa yang berpotensi dijadikan desa wisata di Kawasan Malang Raya. Meksipun demikian, letaknya yang berada di ujung selatan Malang dan jauh dari pusat kota menjadikan desa ini sulit dalam berkembang sebagai desa wisata. Padahal potensi alam yang dimiliki sangat mendukung dalam menjadi desa wisata unggulan di Malang. Desa Gajahrejo berada di wilayah Kecamatan Gedangan, Kabupaten Malang, Provinsi Jawa Timur.

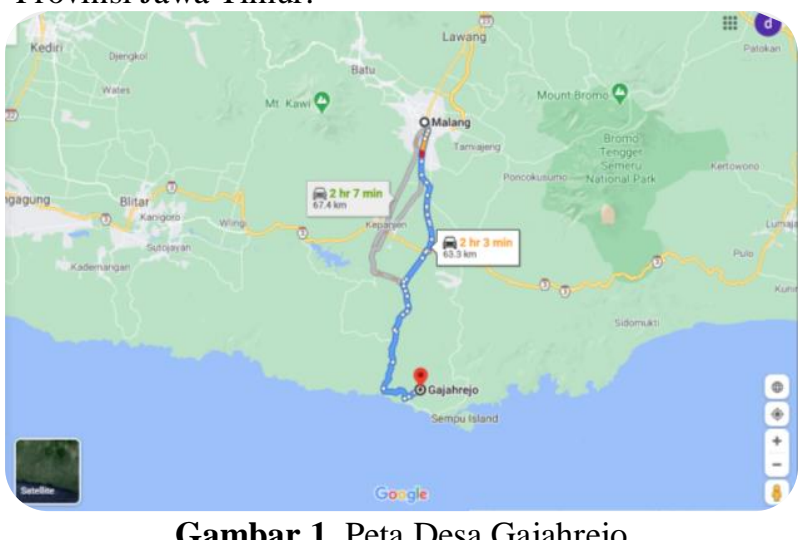

Gambar 1. Peta Desa Gajahrejo

Komitmen pemerintah desa dalam membangun Desa Gajahrejo menjadi desa wisata ditelag ditunjukkan dengan secara perlahan membangun jalan-jalan di penjuru desa. Namun hal itu belum cukup dalam mempercepat pengembangan Desa Gajahreho sebagai desa wisata. Perlu adanya upaya konkrit dalam mempromosikan Desa Gajahrejo serta memperkenalkan potensi yang ada.

\section{METODE}

Program pengabdian ini fokus pada pengembangan website wisata Desa Gajahreho di Kabupaten Malang. Pengabdian ini akan bekerjasama dengan Kepala Desa Gajahrejo dan perangkat Desa Gajahrejo untuk membangun website sesuai dengan kebutuhan desa. Pengembangan website juga memperhatikan beberapa potensi wisata yang di miliki desa. Fokus program pengabdian ini adalah "Pengembangan Website Wisata Desa Gajahrejo dalam meningkatkan daya saing sebagai Destinasi Wisata Unggulan Di Kabupaten Malang”. Adapun tahapan yang dirancang adalah sebagai berikut

1. Persiapan

a) Penyusunan proposal

b) Identifikasi kebutuhan Desa Gajahrejo

c) Koordinasi dengan Kepala Desa dan Perangkat Desa Gajahreho 
d) Identifikasi permasalah dan peluang yang ada di Desa Gajahrejo

e) Pemetaan potensi wisata di Desa Gajahrejo

f) Perencanaan program pengembangan website

2. Pelaksanaan Pembuatan website
a) Analisis
b) Desain
c) Implementasi
d) Testing
e) Deployment
f) Maintenance

3. Evaluasi Program

a) Mencatat permasalahan-permasalahan yang muncul selama proses pelatihan.

b) Mengevaluasi antusias peserta, baik itu umpan balik dan respon dari peserta pelatihan.

c) Membuat notulensi pelaksanaan kegiatan.

\section{HASIL DAN PEMBAHASAN}

\section{Analisis Kebutuhan dan Pemetaan Potensi Wisata}

Proses penentuan kebutuhan dari website wisata di Desa Gajahreho dibantu oleh Kepala Desa dan Perangkat desa. Metode interview digunakan oleh pelaksana dalam mendapatkan data dan gambaran situasi yang ada di Desa Gajahrejo. Permasalahan yang didapat tidak hanya aspek pegembangan desa wisata tapi juga mencakup mengenai masalah penjualan produk-produk yang dihasilkan di Desa Gajahrejo seperti olahan makanan (kripik pisang, nugget kulit pisang, rumput laut) dan bahanan minuman (Kopi). Kondisi ini terkait langsung dengan rencana pengembangan kawasan wisata di Desa Gajahrejo yang juga diharapkan mampu mendongkrak penjualan produk-produk tersebut. Pada akhirnya peningkatan ekonomi adalah kondisi ideal yang diharapkan di Desa Gajahrejo. Selama ini, masalah kemana penjualan masih menjadi kendala dari pelaku usaha produkproduk tersebut. Pengembangan wisata yang diharapkan mampu mendatangkan calon pembeli masih belum bisa terasa dalam jangka pendek. Hal ini juga mengingat butuh waktu untuk menjadikan Desa Gajahrejo sebagai destinasi desa wisata di Malang.

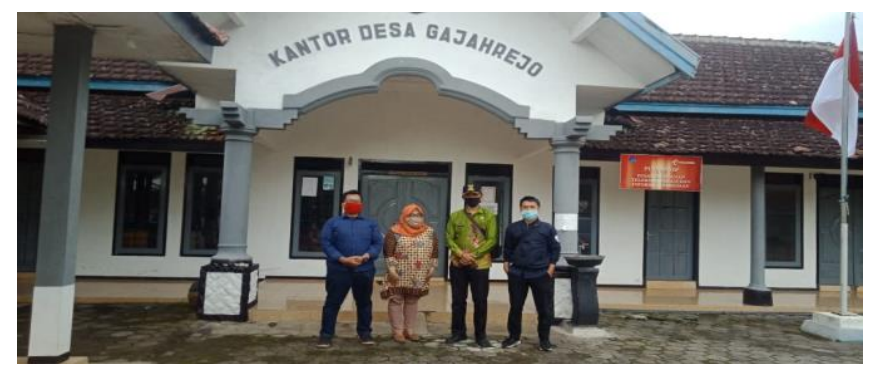

Gambar 2 Kunjungan ke Kantor Desa Gajahrejo
Selain interview, Kepala Desa Gajahrejo juga sempat mengajak tim pelaksana dalam melakukand survey kehidupan masyarakat di Desa Gajahrejo dan spot-spot yang berpotensi untuk dikembangkan sebagai kawasan wisata di garis pantai yang masih masuk ke daerah Gajahrejo. Pada kesempatan yang sama, Kepala Desa Gajahrejo juga sempat menjelaksan visi, misi, dan program kerjanya dalam menciptakan kawasan wisata di Desa Gajahrejo. Beberapa bentang alam seperti garis pantai dan pegunungan menjadi spot unggulan yang berpotensi untuk dikembangkan. Keindahan bentangan alam di Desa Gajahrejo tidak semua bisa diakses dengan mudah.

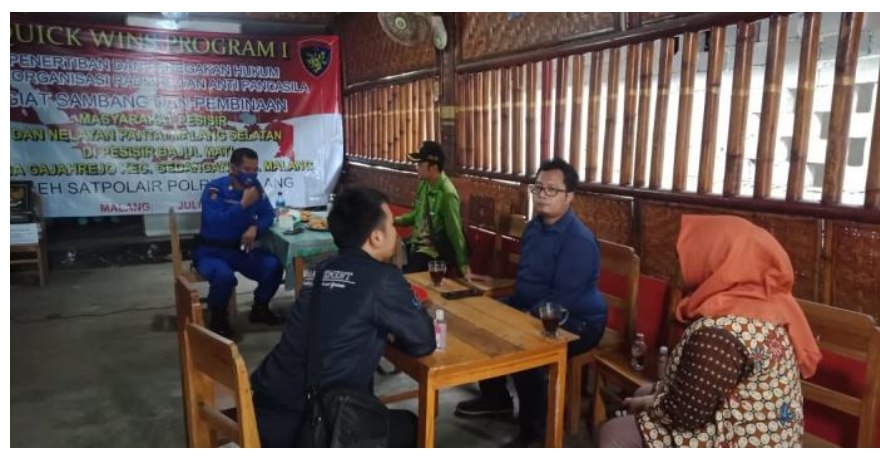

Gambar 3 Survey ke Pantai Bajol Mati

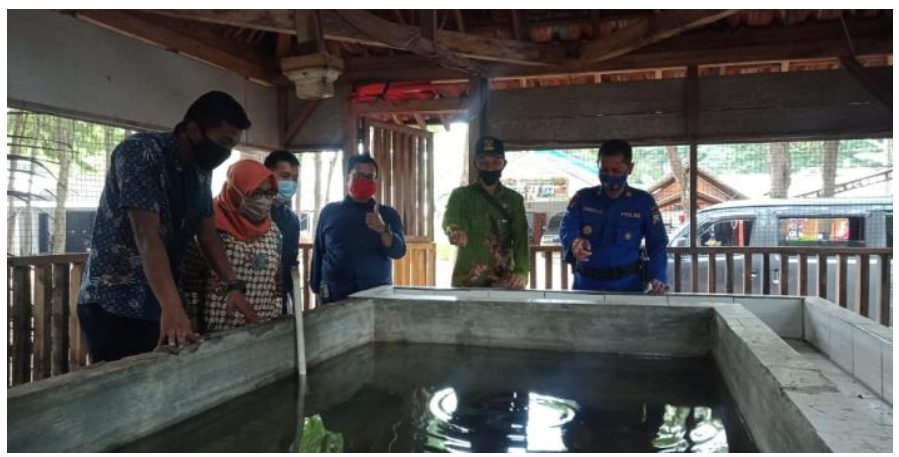

Gambar 4 Survey ke Penangkaran Penyu

Dari proses interview dan survey, tim pelaksana berhasil menyimpulkan bila kebutuhan website adalah memperkenalkan wisata yang dikembangkan di Desa Gajahrejo serta platform untuk memperkenalkan produkproduk yang dihasilkan di Desa Gajahrejo. Website juga lebih baik apabila mampu menyiapkan fasilitas pembelian online dari produk-produk yang dihasilkan oleh masyarakat Desa Gajahreho yang sebagian besar adalah olahan makanan dan minuman seperti kripik pisang, kopi bubuk, nugget, rumput laut, kukus pindang, dan sebagainya. 


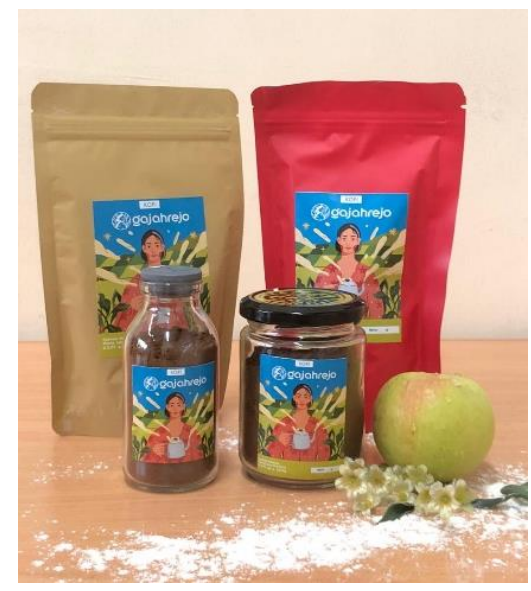

Gambar 5 Contoh Produk Desa Gajahrejo

Dalam pembuatan website ini bertujuan untuk meningkatkan awareness dari produk-produk dari desa gajahrejo ini. Alasan penggunaan website karena website merupakan salah satu media promosi yang mampu memberikan informasi-informasi yang lebih komprehensif. Menurut forbes (2020) website merupakan salah satu upaya untuk konsumen dalam menentukan keputusan dalam pembelian, adanya website juga mampu memberikan validasi terhadap pasar serta mempermudah dalam menganalisis data dari konsumen. Penggunaan website juga salah satu media yang paling sederhana dalam proses transaksi jual-beli melalui daring. Konsep yang sederhana ini yang memberikan kemudahan dalam berbelanja dan kemudahaan penjual (warga desa) dalam mengakses produk produk yang akan di perjual bellikan.

\section{Proses pembuatan website}

Metode pengembangan website ini menggunakan Waterfall method. Waterfall method merupakan pendekatan yang sistematis dan runtut pada pengembangan website. Urutannya dimulai dari tahapan Analisa, yaitu mengumpulkan kebutuhan pengguna dan kemudian dianalisis. Setelah itu masuk ke tahapan desain, implementasi, integrasi komponen dengan proses uji coba, verifikasi, dan yang terakhir adalah maintenance atau perbaikan sistem yang disetujui.

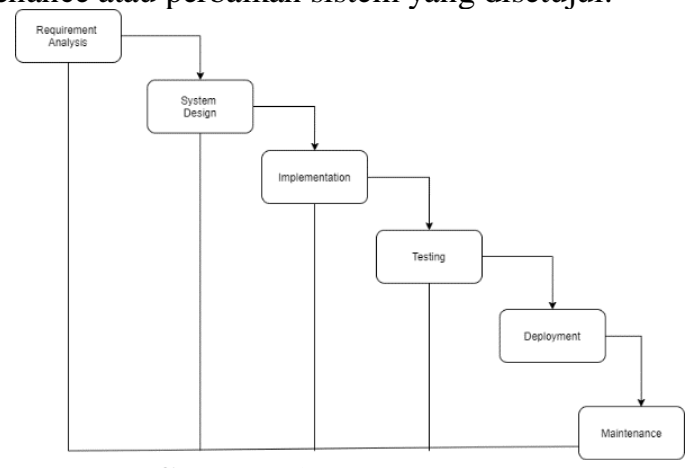

Gambar 6 waterfall method
Pada tahap analisa, dimulai dengan melakukan perencanaan alur sistem navigasi maupun struktur dari website Gajahrejo.id ini. Dalam proses ini menggunakan aplikasi pendukung seperti sublime text, google chrome, photoshop, Xampp, bootstrap, dan codeigniter. Selain itu proses analisis ini juga menganalisis penggunaan bahasa-bahasa pemograman seperti CSS, HTML, Javascipt, dan PHP. Pada intinya, proses analisa ini merupakan proses perencanaan awal sebelum memasuki proses berikutnya.

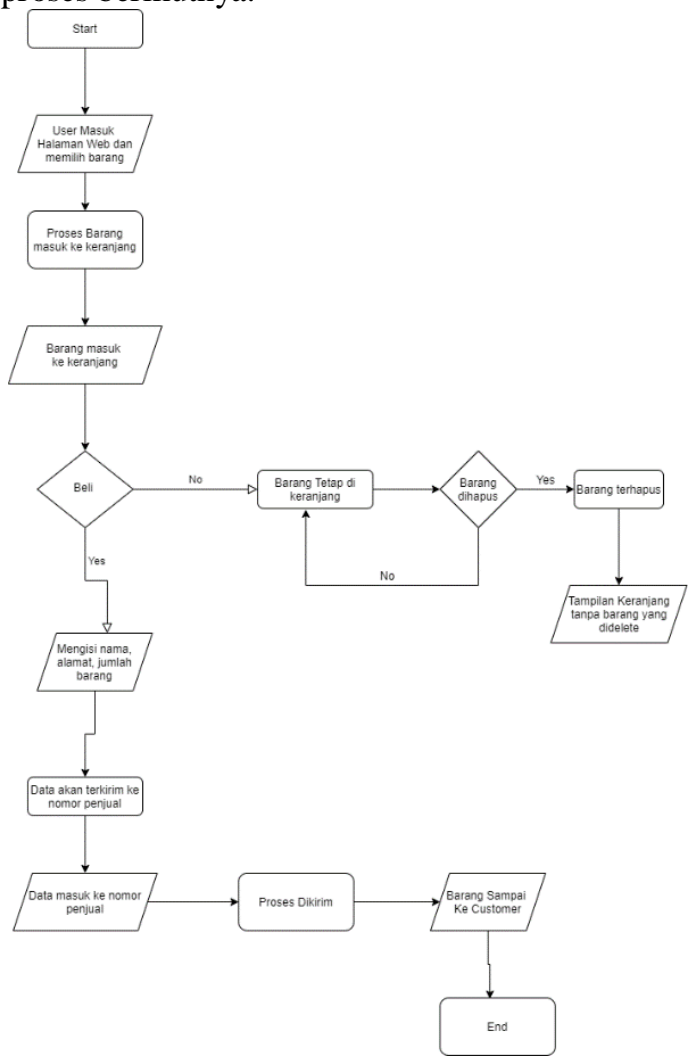

Gambar 7 Alur website

Pada proses desain, dimulai dengan mendesain sesuai dengan architecture website, tema, tata letak, content, dan execution system and sub-system. Dalam website gajahrejo.id memiliki sistem yang sederhana yaitu Login, register, dan Upload. Adapun Sub-sistem seperti E-Receipt. Pada proses desain ini merupakan proses untuk menunjukan user interface maupun user experience yang akan di kembangkan dalam website ini. Proses desain ini akan membantu proses dan alur yang akan dikembangkan dalam sistem website Gajahrejo.id 


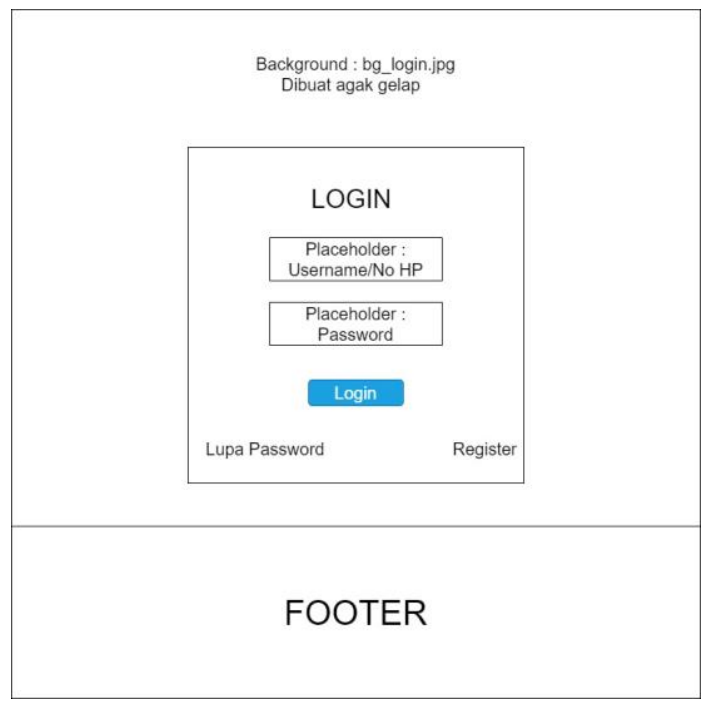

Gambar 8 Struktur Log in Website Gajahrejo.id

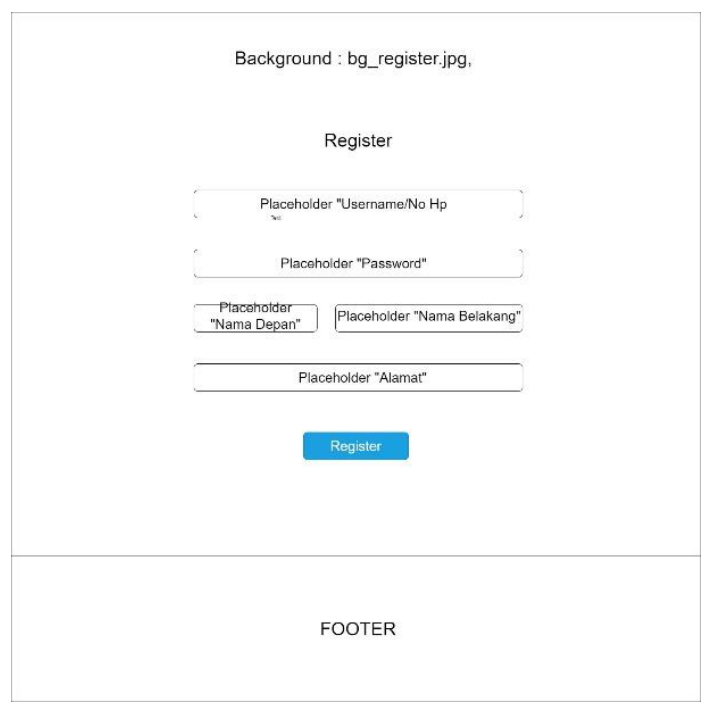

Gambar 9 Struktur Register Website Gajahrejo.id

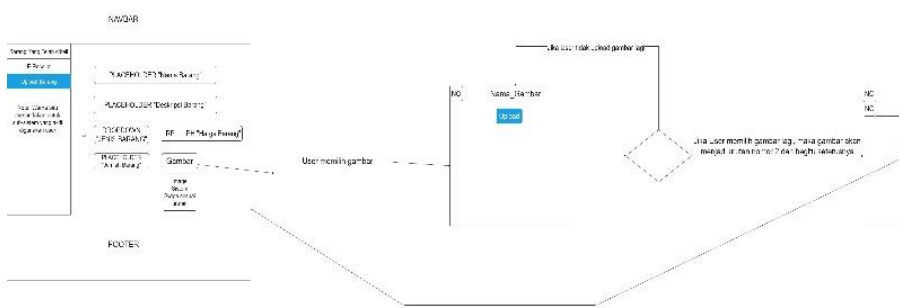

Gambar 10 Navigation Pane

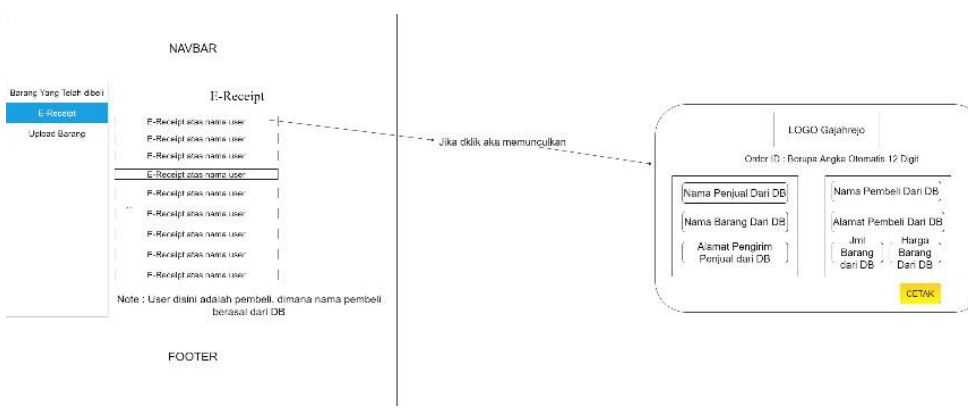

Gambar 11 E-Receipt flow

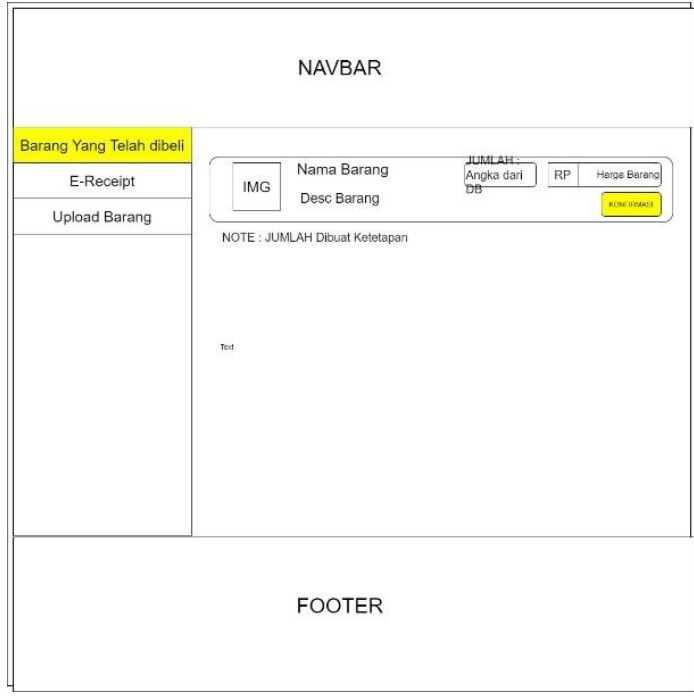

Gambar 12 Struktur Produk yang dibeli

Pada Proses implementasi, dimulai dengan mengintegrasikan proses desain dengan batuan Bahasa pemograman seperti HTML, CSS, dan Javascript. Implementasian merupakan aktivasi dari segala proses analisa, dan desain menjadi sebuah website yang dapat digunakan secara keseluruhan. Pada proses pengimplementasian ini merupakan proses execute visual.

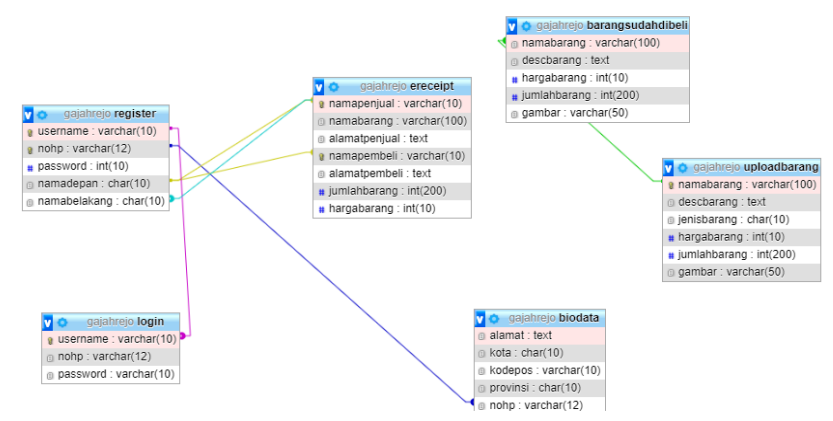

Gambar 13 Site Navigation 
Proses testing merupakan proses diintegrasikan menjadi satu kesatuan kemudian dilakukan uji coba fitur untuk menilai apakah fitur sudah sesuai dan untuk menganalisa kekurangan di setiap fiturnya. Proses uji coba ini akan dilakukan simple test dari sistem dan sub sistem yang di telah di input. Setelah proses ini berhasil dan tidak ada error programmer akan mengmasukan domain dan hostname kedalam sistem.

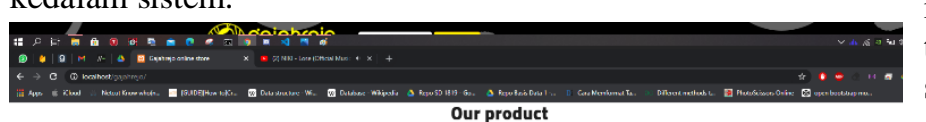

(ㄱ) 00 -

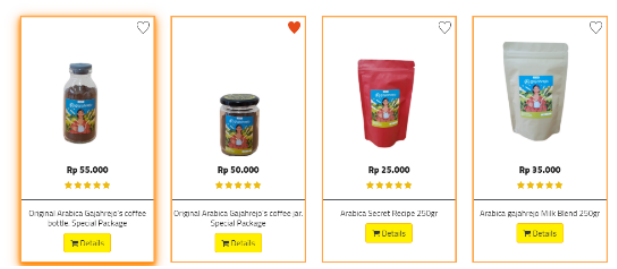

Gambar 14 Salah Satu Tampilan Website Gajahrejo.id

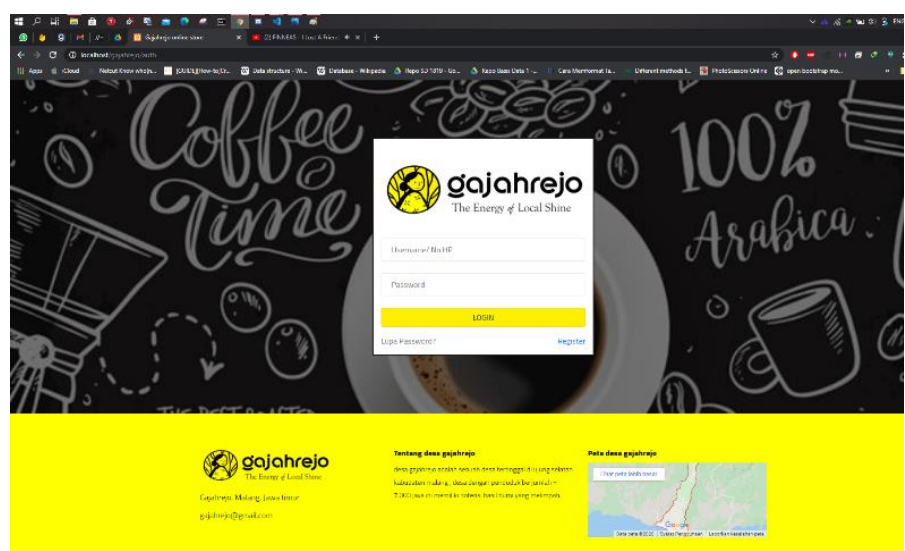

Gambar 15 Salah Satu Tampilan Website Gajahrejo.id

Tahap selanjutnya adalah deployment, proses deployment ini hamper mirip dengan proses uji coba. Namun, kali ini pengguna atau user yang menguji apakah telah memenuhi requirement atau belum. Jikalau sudah, maka website telah terverifikasi (memenuhi requirement dari pengguna). Tahap ini juga merupakan tahap guna meningkaykam sistem yang lebih baik dari kesalahan dan error yang ditemui.

Tahap terakhir dari pengembangan website ini adalah maintenance, Tahap ini merupakan tahap dilakukannya instalasi dan proses perbaikan sistem sesuai yang disetujui. Sebagai contoh, melakukan update pada fitur-fitur tertentu maintenance merupakan proses terakhir apabila terjadi adanya kegagalan sistem yang bisa saja terjadi.

\section{Penentuan Logo}

Dalam memperkuat brand, pelaksana program memutuskan menggunakan domain www.gajahrejo.id. Gajahrejo akan menjadi nama populer baik dari produk-produk desa maupun merek wisata desa. Logo merupakan salah satu identitas dari suatu produk, dalam proses pembuatan website tentunya terdapat point yang tidak terlupakan yaitu logo sebagai salah satu media pengenal. Kami mengkombinasikan unsur culture, warm, and strong. Penggunaan warna kuning merupakan representative dari keramahan masyarakat desa dan energi positif yang ditawarkan. Sedangkan pemilihan warna hitam merupakan representative guna memberikan eksklusivitas dari produk yang di tawarkan.

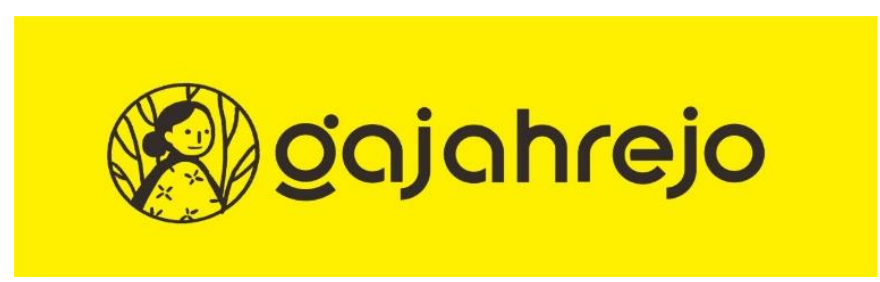

Gambar 16 Logo Gajahrejo.id

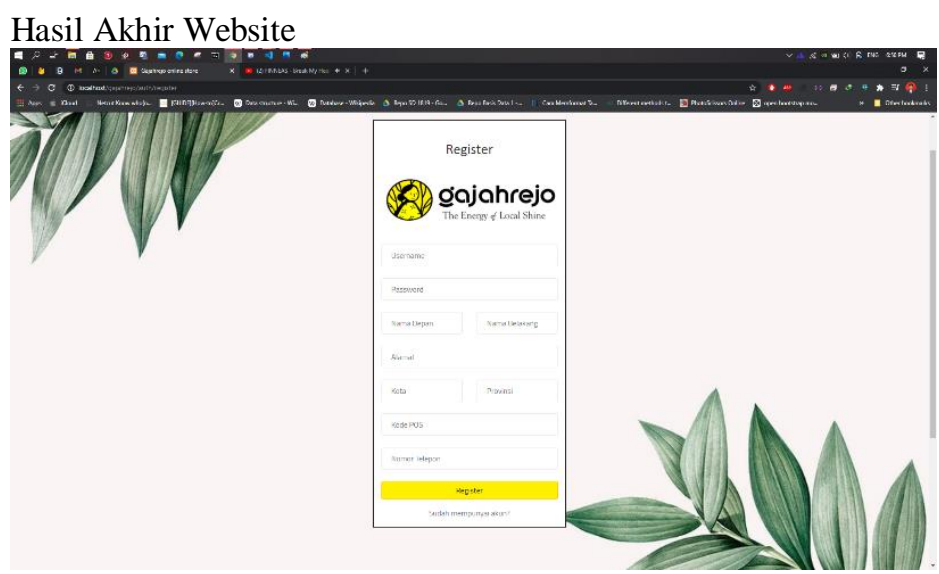

Gambar 17 Menu Register 


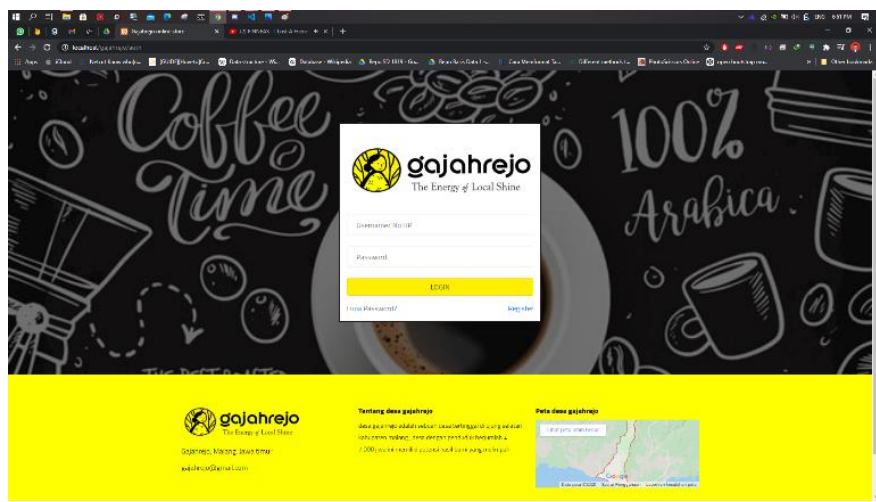

Gambar 18 Halaman Awal Website

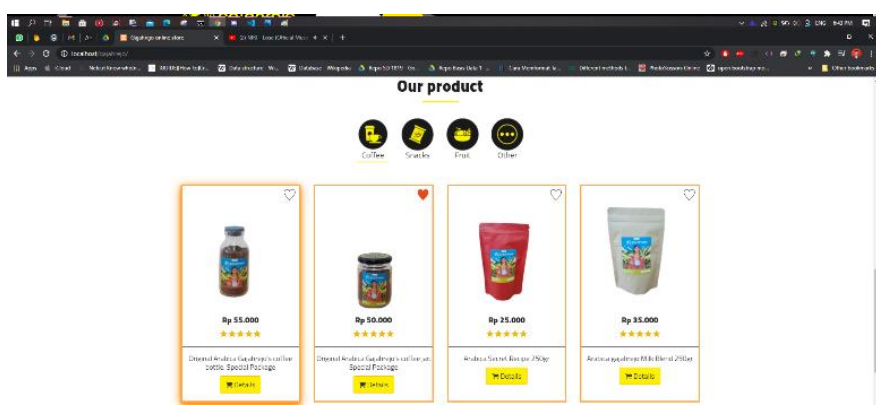

Gambar 19 Product List

\section{KESIMPULAN}

Dari hasil kajian yang dilakukan, pembuatan website Desa Gajahrejo didasarkan pada dua kebutuhan utama yaitu pengenalan Desa Gajahrejo sebagai destinasi desa wisata dan membantu memasarkan (bahkan menjualkan) produk yang dihasilkan oleh masyarakat di Desa Gajahrejo. Keberadaan website Desa Gajahrejo tidak hanya fokus pada pengenalan potensi wisata desa Gajahrejo tetapi juga menjadi platform jual beli online untuk produk-produk yang dihasilkan oleh masyarakat di sana. Website ini akan menjadi sarana dalam memasarkan produk-produk setempat kepada masyarakat di luar desa maupu di luar Malang. Hal tersebut diharapkan lokasi Desa Gajahrejo tidak lagi menjadi masalah dalam menjual produk-produk yang dihasilkan. Keberadaan website ini juga akan memperkenalkan Desa Gajahrejo sebagai salah satu desa wisata yang tidak hanya memiliki wisata alam yang menarik untuk dikunjungi tetapi juga menawarkan produk-produk unggulan oleh masyarakat setempat

\section{UCAPAN TERIMAKASIH}

Penulis menyampaikan terimakasih kepada Kepala Desa dan seluruh masyaraket Desa Gajahrejo Kecamatan Gedangan, Kabupaten Malang yang telah membantu dalam pelaksanaan pengabdian ini baik secara langsung maupun tidak langsung dan semoga program ini bermanfaat bagi masyarakat setempat

\section{DAFTAR PUSTAKA}

[1] Breckling, J., 2012. The analysis of directional time series: applications to wind speed and direction (Vol. 61). Springer Science \& Business Media.

[2] Campón-Cerro, Ana \& Mogollón, José \& Alves, Helena. (2016). Sustainable improvement of competitiveness in rural tourism destinations: The quest for tourist loyalty in Spain. Journal of Destination Marketing \& Management. 10.1016/j.jdmm.2016.04.005.

[3] Hsu, P.H., 2019. Economic impact of wetland ecotourism: an empirical study of Taiwan's Cigu Lagoon area. Tour. Manage. Perspect, 29, 31-40.

[4] https://databoks.katadata.co.id/datapublish/2019/10/18/dayasaing-pariwisata-indonesia-peringkat-empat-di-asia-tenggara

[5] https://www.forbes.com/sites/nicoleleinbachreyhle/2014/09/29/ websites-for-small-businesses/?sh=30f3664a2026

[6] Guaita Martínez, J. M., Martín Martín, J. M., Salinas Fernández, J. A., \& Mogorrón-Guerrero, H. (2019). An analysis of the stability of rural tourism as a desired condition for sustainable tourism. Journal of Business Research, 100, 165174. doi:10.1016/j.jbusres.2019.03.033

[7] Tseng, M.-L., Lin, C., Remen Lin, C.-W., Wu, K.-J., \& Sriphon, T. (2019). Ecotourism development in Thailand: community participation leads to the value of attractions

[8] Zhang, S., Zhu, C., Sin, J.K. and Mok, P.K., 1999. A novel ultrathin elevated channel low-temperature poly-Si TFT. IEEE Electron Device Letters, 20(11), pp.569-571 